\title{
Attributable risk of Capillaria species in domestic pigeons (Columba livia domestica)
}

\author{
[Risco atribuível de espécies Capillaria em pombos domésticos \\ (Columba livia domestica)] \\ M.F. Qamar ${ }^{1}$, A. Butt ${ }^{2}$, S. Ehtisham-ul-Haque ${ }^{1}$, M.A. Zaman ${ }^{1}$ \\ ${ }^{1}$ Department of Pathobiology, University of Veterinary and Animal Sciences, \\ Lahore (Jhang campus), Pakistan \\ ${ }^{2}$ GC University, Lahore, Pakistan
}

\begin{abstract}
Fecal samples were collected from 120 domestic pigeons to determine the Attributable risk of Capillaria spp. The Capillaria spp. was observed in 64 out of $120(51 \%)$ pigeons (70 males and 50 females) under this study. A total of 64 (39 males and 25 females) were found naturally infected with Capillaria spp. with infection percentage of $51 \%$ and $50 \%$ in males and females respectively. Qualitative examinations include the direct microscopy and faecal floatation while quantitative examination includes McMaster technique (worms load was calculated per gram of the faeces). Month wise Attributable risk showed that eggs of the worms were found to be abundant in the month of July during the present study (60\% to $73 \%$ ) because of high humidity. Very high and very low temperature is not suitable for the proper development of the eggs. Qualitative and quantitative examination revealed that Capillaria spp. was more prevalent in males $(51 \%)$ than females $(50 \%)$ but overall there was no significant difference $(\mathrm{P}>0.05)$ in the male and female because both individuals invest equal amount of energy in search of food and incubating the eggs. Different breeds of pigeons gave different Attributable risk in different months during the study. Groups of pigeons from different locations showed different variable Attributable risk. Areas with high humidity were more suitable for the development of eggs, which is the reason why higher Attributable risk was observed in Shahdara (75\%) area of Lahore, Pakistan.
\end{abstract}

Keywords: Attributable risk, Capillaria species, pigeons, Pakistan

\section{RESUMO}

Amostras de fezes foram coletadas de 120 pombos domésticos para determinar os fatores de risco de Capillaria spp. Capillaria spp. foi observado em 64 de 120 (51\%) pombos (70 machos e 50 fêmeas) neste estudo. Um total de 64 (39 machos e 25 fêmeas) foram naturalmente infectados com Capillaria spp. sendo $51 \%$ em machos e $50 \%$ em fêmeas. Exames qualitativos incluem microscopia direta e suspensão de fezes, e exames quantitativos incluem a técnica McMaster (vermes são calculados por grama de fezes). $O$ risco por mês demonstrou que ovos dos vermes foram encontrados em abundância no mês de Julho durante o presente estudo (60\% a $73 \%$ ) por causa da alta umidade. Temperaturas muito altas e muito baixas não são adequadas para o desenvolvimento adequado de ovos. $O$ exame qualitativo e quantitativo revelou que Capillaria spp. era mais prevalente em machos (51\%) que em fêmeas (50\%), mas no geral não houve diferença significativa $(P>0.05)$ entre machos e fêmeas porque ambos investem a mesma energia na busca por alimento e incubação de ovos. Diferentes raças de pombos tem diferentes riscos em diferentes meses durante o estudo. Grupos de pombos de diferentes locais demonstraram risco diferenciado. Áreas com alta umidade eram mais propensas para o desenvolvimento de ovos, o motivo pelo qual maior risco foi observado em shahdara (75\%).

Palavras-chave: pombos, risco atribuível, espécies Capillaria, Paquistão

Recebido em 13 de julho de 2014

Aceito em 12 de março de 2015

E-mail: fiaz.qamar@uvas.edu.pk 


\section{INTRODUCTION}

Pigeons are found in almost all regions of the world except the poles. Pigeons have greater interaction with human beings and other animal species. Pigeons can be bred as a source of food, symbolize a hobby or have experimental purposes (Cooper, 1984 and Harlin, 1994). Pigeons are the most common birds in rural and urban environments. Unfortunately pigeons have a dependence upon people for food because the bird lovers feed them. They are used to living on signs, ledges and make their nest almost anywhere by bringing the nesting material everywhere (Razmi et al, 2007 and Rehman, 1993).

Pigeons are fast flying birds and feed mostly on ground. But one group of pigeons feed on ripe fruits in the trees. Pigeons are used for biomedical researches and raised for meat production (Levi, 1974). Pigeons make pairs and their squabs are brood and fed by their parents until they reach the age of 4 weeks. One pair of pigeons can give rise to 15 squabs per year (Soulsby, 1982). Pigeons are traditionally living in association with humans and are found everywhere on the globe. This association was reported from 3000B.C-5000B.C (Sati et al., 2008). In the rural areas of Pakistan pigeons are thought to be a symbol of culture, and they are bred as food and for trading purposes (Tanveer et al., 2011). Poultry producers are searching for a substitution for chicken meat, which will be in the form of pigeon meat in the near future. It will increase the gross domestic production. Pigeons can be divided into three groups i.e. poultry pigeons, carrier pigeons, fancy and feral pigeons. This distribution has made them an easy subject for research and study purposes. Pigeons are mostly domesticated and live side by side with human beings. Their breeding rate is very fast and they produce greater varieties in a short time (Urquhart, 1996).

Pigeons are related to ancient times and are considered to be cosmopolitan (sari et al., 2008) and pigeons of the columbiforme order are thought to be found in every town and city around the world (Marques et al., 2007). The poultry industry is facing various parasitic diseases of economic importance (Anwar et al., 2000). Like poultry animals, pigeons have shown high prevalence of GIT helminthes and protozoan infections (Ghazi et al., 2002; Adang et al., 2008). They are a major source of infection and transmission for humans and birds like ducks and chicks (Patel et al., 2000). Endoparasitism, one of the more significant disease occurrences, has been reported for different species of cestode in poultry (AlBayati, 2011; Dranzoa et al., 1999). Endoparasites dilate the intestine; produce nodule and severe enteritis, thus impairing the absorbing power of the intestine for nutrients and vitamins from the host (Anwar et al., 2000).

Fancy and racing pigeons are kept for hobby. Pigeons are cheap and readily available, which makes them ideal for laboratory and research in Pakistan. Pigeons have close association with other domestic birds, which increases the risk of parasitism and zoonotic disease in human beings (Cooper 1984; Kaninjolo et al., 1988; Piasecki, 2006; Marques et al, 2007; sari et al., 2008). The importance of pigeons can't be ignored because pigeons act as reservoir hosts or carriers and an important source for the infection in birds (Kumar, 1998). Pigeons are usually infected by the Gastrointestinal and hematazoan parasites (Kaminjo, et al., 1988: Ghazi et al., 2002). Pigeons have been considered to transmit diseases in humans and other birds (Patel et al., 2000). Nematodes with high prevalence in pigeons are Ascardia columbae, Disphyranx species and Capillaria species (Dovc et al., 2004).

The diseases are usually spread by dust particles present on the feces from the cages that have been contaminated with the droppings and urine (Marques et al., 2007). Blood and fecal samples of the pigeons are used to approach the pathological and physiological status of exposed animals to the pathogenic organism (Joshi et al., 2002). Parasites can affect domestic chickens, pigeons, duck, canaries and falcons (Brossy, 1992; William, 2005). Diseases caused by the parasites in birds are fever, anorexia, nephritis, fatty liver, lymphocytosis, oedema in lungs and occlusion of brain capillaries (Jordan and Pattison, 1996; Aiello and Mays, 1998). The Gastrointestinal tract of pigeons has a large number of helminthes, of which nematodes are most harmful and are responsible for symptomatic and asymptomatic parasitism (Adang et al., 2008). When the nematode infection is heavy it cause serious effects on the 
health of pigeons i.e. weight loss, retarded growth, unthriftiness, damage to gut, epithelium fertility disturbances, emaciation and death in young birds (Urquhart, 1996).

Very little attention in terms of research has been given to pigeons due to their perceived little importance. Moreover, internal and external infections and parasites are common (Senlik et al., 2005; Marques et al., 2007). Gastrointestinal parasites in birds are not properly investigated. Columbidae family results showed that $29.9 \%$ of the birds were positive for helminthes and protozoa; Capillaria sp was the most prevalent parasite in addition to Ascardia sp.

Parasites are endemic in Africa, Central and South America, certain Caribbean islands and parts of Asia, with a wide variety of hosts and vectors. Many species of parasites have been isolated from birds and only few are pathogenic. Parasites infect domestic chickens, penguins, ducks, canaries, falcons, pigeons and several marine avifaunas (Brossy, 1992; William, 2005). Parasitic diseases in birds are associated with clinical signs such as fever, depression, anorexia, loss of body weight, dyspnea, hepatomegaly, spleenomegaly, ocular haemorrhage, haemolytic anaemia, haemoglobinuria, leukocytosis, lymphocytosis, hypoalbuminaemia, nephritis, fatty liver, oedema of the lungs, hydropericardium and occlusion of capillaries of the brain (Jordan and Pattison, 1996; Aiello and Mays, I998; William, 2005).

Nematodes belonging to the genus capillaria occur in the digestive tract of the birds anterior to the intestine. The infestations of the Capillaria have frequently been severe. Stomach, intestine, esophagus and crop have been affected. Nematode constitutes an important group of poultry helminthes, both in terms of species and pathology. Species of the genus Hetarakis, Ascardia, capillaria and syngamous are generally the most important nematode. Capillaria species can cause production losses in breeders and can cause a significant growth depression and mortality in birds (Permin et al., 1999. The nematode has been identified belonging to two species of capillaria i.e. Capillaria anulata and
C.contorta. Capillaria are thread like worms just behind the head region in adult specimen a bulbous swelling of cuticle and somewhat more posterior in cervical regions. Wavy transverse folds give the appearance of bladder like swelling in the optical section. The Capillaria species of nematode or roundworm are intestinal worms that can cause severe symptoms such as diarrhea, weakness, weight loss and drop in egg production. The condition is sometimes referred to as capillariasis. There are several species of Capillaria, and they cause paralysis of different parts of the alimentary tract, including the crop, esophagus and the intestinal tract. Commonly, the Capillaria species are referred to as the threadworm or hairworm, and they can be highly pathogenic, causing severe diseases. Capillaria columbae and C.longicollis are fine thread worms found in the intestine of pigeons and produce characteristic lemon shaped bipolar eggs. Capillaria columbae and C. longicollis are fine threadworms found in racing pigeons' small intestines that produce characteristic lemon shaped bipolar eggs. Clinically, capillariasis in racing pigeons can present severe illness and it has been suggested that worms may affect race performance.

The main site of infection of C. bursata, C. caudinflata and $\mathrm{C}$. obsignata is the small intestine. Capillaria anatis is a parasite of the caecum and is found mainly in ducks. The main species afflicting turkeys and game birds are $\mathrm{C}$. annulata and C. contorta. Capillaria obsignata $(53.6 \%)$, Capillaria anatis $(31.9 \%)$ and Capillaria caudinflata $(1.5 \%)$ have been found in organic/free range systems in Denmark (Permin et al, 1999). Amongst Dutch organic poultry farms, Capillaria, along with coccidiosis, was the second most prevalent internal parasite, being present in $30 \%$ of the faeces samples examined (Iepema et al., 2006). The worm burrows deep in the intestinal mucosa resulting in the epithelial necrosis, inflammation and hemorrhage (Wehr, 1939).

The main aim objective of this study was to determine the incidence of Capillaria spp. in pigeons regarding sex, seasons, breeds and location of the pigeons. 


\section{MATERIALS AND METHODS}

Capillaria are thread like worms just behind the head region. In adult specimen a bulbous swelling of cuticle and somewhat more posterior wavy transverse folds in cervical regions give the appearance of bladder like swelling in the optical section.

The study was conducted over a period of 7 months from January to July 2013.

To conduct this study about 120 pigeons were collected from different regions of Lahore. Of these 120 pigeons 70 were male and 50 were female. The collection of the pigeons was done on a monthly basis over the research period and studied for incidence of Capillaria spp.

The samples were collected from different regions of Lahore. The selected areas were Data Darbar, Tollinton market, Shahdra, Shadman market of birds and Qurtaba Chowk.

20 pigeons were collected from each region mentioned above. A total of 120 pigeons were collected from 5 regions. The collected pigeons were put in the cage present in the GCU Lahore department of Zoology. Each pigeon was labeled with the necessary information (sex, age, weight). Food and water was provided carefully and the cages were kept clean.

Fresh fecal samples were collected from the floor of the cage. The upper layer of the feces was removed to avoid the fecal contamination. All the fecal samples were collected in Petri plates. The fecal samples were checked immediately after collection and some of the material was preserved in $10 \%$ formalin solution for further studies (MAFF, 1986).

Qualitative and quantitative examination was done with the fecal sample (Cringoli, et al., 2010). Direct microscopy and Flotation method was done for the qualitative examination and the McMaster technique was done for quantitative examination.

A small amount of fecal sample was taken with the help of a tooth pick and placed on a neat and clean grease free glass slide. The fecal sample was mixed with 1 to 2 drops of water and all the debris present in the sample were removed with the help of a glass slide. A clean cover slip was placed on the glass slide to avoid the formation of bubbles and the slide was observed under microscope at 10X and 40X (Greiner, 1989).

A number of different methods are available for separating, concentrating and demonstrating eggs.

1. Simple test tube flotation

\section{Simple flotation}

The simple test tube flotation method is a qualitative test for the detection of nematode and cestode eggs and coccidia oocysts in the faeces. It is based on the separating of eggs from faecal material and concentrating them by means of a flotation fluid with an appropriate specific gravity. This is a good technique to use in initial surveys to establish which groups of parasites are present (Karamon, et al., 2008).

The McMaster counting technique is a quantitative technique to determine the number of eggs present per gram of faeces (EPG). A flotation fluid is used to separate eggs from faecal material in a counting chamber (McMaster) with two compartments. The technique described below will detect 50 or more EPG of faeces. This technique can be used to provide a quantitative estimate of egg output for nematodes, cestodes and coccidia. Its use to quantify levels of infection is limited by the factors governing egg excretion (Soulsby, 1982).

Statistical analysis was done with the help of SPSS software version 15. Chi- squared test was used to analyze the variations in incidence of Capillaria spp. of male and female pigeons and variations in the incidence of Capillaria spp. in different localities. $(\mathrm{P}<0.05)$ was considered as significant.

\section{RESULTS}

Qualitative examination of 120 pigeons revealed 64 samples (53\%) with parasitic infection. Quantitative examination for Capillaria infection was high during monsoon season. Lower rate of infection was in very cold and very hot months.

Pigeon's sex wise incidence of Capillaria was recorded and shown in Table 1 and Figure 1. 
Males were more infected than females. Total pigeons observed during this study were 120 and of 120,64 were infected $(53 \%)$. Of 120 pigeons, 70 were males and 50 were females of 70 males, 39 were infected with Capillaria spp. Of 50 females, 25 were infected. In males a $51 \%$ incidence was recorded and in females a $50 \%$ incidence was recorded. The overall incidence in males and females was found to be $53 \%$. Statistical analysis showed that there was no significant difference in the incidence of Capillaria spp. in males and females $(\mathrm{P}>0.05)$.

Table 1. Pigeon's sex wise incidence of Capillaria spp.

\begin{tabular}{ccccc}
\hline Sex & Total no. of pigeons & No. of infected samples $(\mathrm{n})$ & Incidence $(\%)$ & $\mathrm{P}$ value \\
\hline Male & 70 & 39 & 51 & $>0.56, \mathrm{NS}$ \\
Female & 50 & 25 & 50 & $>0.40$, NS \\
Total & 120 & 64 & 53 & - \\
\hline
\end{tabular}

Chi-squared test; N.S describes Non-significant $(\mathrm{P}<0.05$ was considered as significant).

Month wise incidence of Capillaria was recorded and is shown in Table 2 and Figure 2. The range of monthly incidence was $33-73 \%$. In January 20 pigeons (13 males and 7 females) were taken. $8 / 13$ males and 4/7 females were infected. Males showed a $61 \%$ incidence and females showed a $57 \%$ incidence. In February 20 pigeons were taken (12 males and 8 females). 7/12 males and $4 / 8$ females were infected. Males showed a $58 \%$ incidence and females showed a $50 \%$ incidence. In March 20 pigeons were taken (13 males and 7 females). 8/13 males and 4/7 females were infected. Males showed a $61 \%$ incidence and females showed a $57 \%$ incidence. In April 20 pigeons were taken (14 males and 6 females). 8/14 males and 3/6 females were infected. Males showed a $57 \%$ and females showed a $50 \%$ incidence. In May 20 pigeons (11 males and 9 females) were taken. 6/11 males and 4/9 females were infected and showed 54\% and $33 \%$ incidence respectively. In June 20 pigeons (13 males and 7 females) were taken and 8/13 males and 4/4 females were infected. Males showed a $61 \%$ incidence and females showed a $57 \%$ incidence. In July 20 pigeons (15 males and 5 females) were taken. $11 / 15$ males and $3 / 5$ females were infected and showed $73 \%$ and $60 \%$ incidence respectively.

Table 2. Month wise incidence of Capillaria spp. in Male and Female

\begin{tabular}{|c|c|c|c|c|c|c|c|}
\hline \multirow[t]{2}{*}{ Months } & \multirow{2}{*}{$\begin{array}{c}\text { \# of } \\
\text { pigeons }\end{array}$} & \multicolumn{3}{|c|}{ Male pigeons } & \multicolumn{3}{|c|}{ Female pigeons } \\
\hline & & & \# infected & $\%$ incidence & $\#$ & \# infected & $\%$ incidence \\
\hline Jan & 20 & 13 & 08 & 61 & 7 & 4 & 57 \\
\hline Feb & 20 & 12 & 07 & 58 & 8 & 4 & 50 \\
\hline March & 20 & 13 & 08 & 61 & 7 & 4 & 57 \\
\hline April & 20 & 14 & 08 & 57 & 6 & 3 & 50 \\
\hline May & 20 & 11 & 06 & 54 & 9 & 4 & 33 \\
\hline June & 20 & 13 & 08 & 61 & 7 & 4 & 57 \\
\hline July & 20 & 15 & 11 & 73 & 05 & 3 & 60 \\
\hline
\end{tabular}

EPG of Capillaria spp. was counted according to the Breed of the pigeons. EPG results showed that all types of pigeons were highly infected with Capillaria in July during monsoon, less infected in moderate temperatures and moderate humidity and very low infection was observed in intense weather. In black and white pigeons 300 to 900 eggs of Capillaria spp. were counted thorough McMaster slide. 400 to 800 eggs were counted from brown and white pigeons from
January to July. In white pigeons 500 to 800 eggs were counted from January to July. In brown pigeons 400 to $800 \mathrm{eggs}$ were counted from January to July and in shirazi pigeons 500 to 900 eggs were counted (Table 3 and Figure 3a, 3b). T-test was used to analyze the data of EPG statistically, unpaired t-test gave $(\mathrm{P}<0.05)$ which indicated that the incidence in EPG varies significantly month wise. 
Table 3. Pigeon's breed wise EPG

\begin{tabular}{|c|c|c|c|c|c|c|c|c|c|c|}
\hline $\begin{array}{l}\text { Sr. } \\
\text { no }\end{array}$ & $\begin{array}{l}\text { Breeds } \\
\text { of pigeons }\end{array}$ & $\begin{array}{r}\text { Parasite } \\
\text { or ova }\end{array}$ & No & Jan & Feb & March & April & May & June & July \\
\hline 1 & $\begin{array}{l}\text { Black } \\
\text { and white } \\
\text { pigeon }\end{array}$ & $\begin{array}{c}\text { Eggs of } \\
\text { Capillaria } \\
\text { spp }\end{array}$ & 20 & 300 & 500 & 600 & 800 & 700 & 400 & $\overline{900}$ \\
\hline 2 & $\begin{array}{l}\text { White } \\
\text { and brown } \\
\text { pigeon }\end{array}$ & ${ }^{{ }^{5} P P}$ & 20 & 500 & 400 & 700 & 700 & 700 & 400 & 800 \\
\hline 3 & $\begin{array}{l}\text { White pig } \\
\text { Eon }\end{array}$ & - & 20 & 600 & 600 & 700 & 700 & 500 & 500 & 800 \\
\hline 4 & $\begin{array}{l}\text { Brown } \\
\text { pigeon }\end{array}$ & - & 20 & 400 & 600 & 600 & 800 & 500 & 400 & 1000 \\
\hline 5 & Shirazi & - & 20 & 500 & 400 & 500 & 800 & 500 & 500 & 900 \\
\hline
\end{tabular}

T-test; N.S describes significant ( $\mathrm{P}<0.05$ was considered as significant).

Location wise incidence of Capillaria was recorded and is shown in Table 4 and Figure 4. The range of incidence was $50 \%$ to $65 \%$. The region with highly infected pigeons was Shahdara. This might be due to the high humidity in this region. But some regions showed no significant variations because of the same climatic conditions. From the Tollinton market 20 pigeons were examined and 11 of these 20 were infected with $55 \%$ incidence. From
Data durbar 12 pigeons were infected with $60 \%$ incidence. 20 pigeons were taken from Shahdra and of these 13 were infected and showed $65 \%$ incidence. From Qurtaba chowk 11 pigeons were infected and showed 55\% incidence. 10 pigeons were infected from Shadman and Abdali chowk with an incidence of $50 \%$. Statistically there was no significant variation in the incidence of Capillaria spp .in different locations $(\mathrm{P}>0.05)$.

Table 4. Location wise incidence of Capillaria spp.

\begin{tabular}{lcccc}
\hline Localities & \# of samples examined\# of positive samples & \% incidence & P value \\
\hline Tollinton & 20 & 11 & 55 & $>0.45$ \\
Data darbar & 20 & 12 & 60 & $>0.51$ \\
Shahdara & 20 & 13 & 65 & $>0.59$ \\
Qurtaba chowk & 20 & 11 & 55 & $>0.45$ \\
Shadman market of birds & 20 & 10 & 50 & $>0.40$ \\
Abdali chowk & 20 & 10 & $50 \%$ & $>0.40$ \\
\hline
\end{tabular}

Chi-squared test; N.S describes Non-significant ( $\mathrm{P}<0.05$ was considered as significant).

\section{DISCUSSION}

The present study deals with the incidence of Capillaria spp. in pigeons regarding sex, season, breed and location. Capillaria are thread like worms just behind the head region, and in adult specimen a bulbous swelling of cuticle and somewhat more posterior, in cervical regions, wavy transverse folds give the appearance of bladder like swelling in the optical section. Capillaria columbae and $\mathrm{C}$.longicollis are fine thread worms found in the intestine of pigeons and produce characteristic lemon shaped bipolar eggs. Capillaria columbae and $\mathrm{C}$. longicollis are fine threadworms found in racing pigeons' small intestines that produce characteristic lemon shaped bipolar eggs. Clinically, capillariasis in racing pigeons can present severe illness and it has been suggested that worms may affect race performance (Javid et al., 2013). Qualitative examination of 120 pigeons revealed 64 samples (53\%) with parasitic infection. Quantitative examination for Capillaria infection was high during monsoon season. This may be due to mean temperature and high relative humidity which lowers the resistance of birds and favors heavy infection (Hawkins, 1945). Lower rate of infection was in highly cold and highly hot months. Very high and very low temperature is not suitable for the proper development of parasites and their eggs. The infection rate was moderate during mild winter and mild summer. This might be attributed to low temperature, 
which also helped in arrested development of parasite in the host and environment.

In present study the total 120 pigeons were examined and of these 120 pigeons 64 (53\%) were infected with Capillaria spp. This high prevalence $(53 \%)$ of gastrointestinal nematodes including the Capillaria spp in domestic pigeons corresponded with the studies of Basit et al (2006), who found an overall 57\% infestation rate in pigeons $(60 \%$ and $55 \%$ in wild and domestic pigeons, respectively). However 53\% incidence was dissimilar to $67.2 \%$ Capillaria spp. reported by Tanveer et al., (2011). But high infection in males when compared to females in the present study is in agreement with Tanveer et al., (2011). Statistically, there was no significant difference $(\mathrm{P}>0.05)$ observed in the prevalence of gastrointestinal nematodes between male and female domestic pigeons. Similarly, nonsignificant sex related difference in the prevalence of Capillaria spp. in domestic pigeons was also found according to the findings of Senlik et al. (2005). This insignificant difference might be due to close association of male and female domestic pigeons for food and flight, therefore equal possibility of being infested by gastrointestinal nematodes from the environment. In 2000, a research conducted by Gicik \& Burgu concluded that there is no significant difference in the overall helminthes infection between male and female wild pigeons. Sandra et al in 2007 studied the helminthes of intestine and they reported about $32.56 \%$ Capillaria spp. Dehlawi in 2007 worked on 32 breeds of birds that were naturally infected with the nematodes. One hundred and three faecal samples were collected and examined. Of these, $3.6 \%$ carrier pigeons and $36.4 \%$ fancy pigeons were infected with Capillaria spp. Naem (2013) studied the haematic gastrointestinal parasites of domestic pigeons and found the Capiilaria spp. $(10.1 \%)$. The present study was also found to be similar to $53.57 \%$ Capillaria spp. reported by Patel, 2000. This incidence was also very near to the results of Borghare et al., (2009) who reported $56.66 \%$ Capillaria in pigeons. The results of the present study also did not match results by Ibrahim et al. (1995) who reported only $4.8 \%$ Capillaria spp. In Egypt, Bahrami et al., (2011) reported 6\% Capillaria spp. which also disagreed with the present study. Differences in the number of birds examined and the prevailing environmental conditions and availability of intermediate hosts in the study area may have been responsible for the difference in the Incidence observed. The variations in the incidence indicates that parasites are present but not as high as reported by Borghare et al. (2009); Tanveer et al., (2011). This means that the factor for the spread of the nematode was not appropriate. Leningrad (1999) pointed out that an increase in temperature to certain limits accelerates the fission and larval development of intermediate stages of helminthes parasites. The increase in temperature probably caused the egg degeneration which may destroy many parasites before becoming adults. The variations in the incidence are observed due to the geological and climatic conditions.

Every region of the world is different regarding its climatic conditions. Therefore, the number of eggs or the percentage incidence varies in different regions. Suitable conditions for the development of the eggs of the Capillaria spp. are moderate temperature and high humidity. Therefore in the present study the eggs of the Capillaria spp. were found to be abundant during monsoon season. Very high and very low temperature does not support the development of the Capillaria spp.

\section{CONCLUSION}

From the present study it was concluded that eggs of Capillaria spp. are found to be abundant in the presence of high humidity, as they require high humidity and moderate temperature for proper development. Both males and females were affected with Capillaria spp. but males were more affected when compared to females. The affected individuals showed various signs of infection, such as anemia, emaciation, weight loss, regurgitation, diarrhea and low breeding rate. 


\section{REFERENCES}

ADANG, K.L.; ONIYE, S.J.; AJANUSI, O.J. et al. Gastrointestinal helminthes of the domestic pigeons in Zaria, Nigeria. Sci. World J., v.3, p.33-37, 2008.

AIELLO, S.E.; MAYS, A. The Merck veterinary manual. 8. ed. New Jersey: Wiley, John \& Sons, 1998. 2305p.

AL-BAYATI N.Y. A study on pigeons (columba livia) cestodes infection in Diyala Province Diyala. Agric. Sci. J., v.3, p.1-12, 2011.

ANWAR, A.H.; RANA, S.H.; SHAH, A.H. Pathology of cestodes infection in indigenous and exotic layers. Path. J. Agri. Sci., v.37, p.1-2, 2000 .

BAHRAMI, A.; NASROLAHI, O.A.; AHMADY, S. et al. Survey of egg per gram (EPG) parasite ovum in pigeon. International $\mathrm{J}$. Mol. Clin. Microbiol., v.1, p.103-106, 2011.

BASIT, T.; PERVEZ, K.; AVAIS, M.; RABBANI, I. Prevelance and chemotherapy of nematodes infestation in wild anddomestic pigeons and its effects onvarious blood components. J. Anim. Plant Sci., v.16, p.1-2, 2006.

BORGHARE, A.T.; BAGDE, V.P.; JAULKAR, A.D. et al. Incidence of gastrointestinal parasitism of captive wild pigeons at Nagpur. Vet. World, v.2, p.343, 2009.

Brossy, J. J. Malaria in wild and captive Jackass penguins, Spheniscus dermersus, along the southern African coast. Ostrich, v.63: p. 10-12. 1992.

COOPER, J.E. A veterinary approach to pigeons. J. Small Anim., v.25, p.505-516, 1984.

CRINGOLI, G.; RINALDI, L.; MAURELLI, M.P.; UTZINGER, J. Flotac: new 468 multivalent techniques for qualitative and quantitative copromicroscopic diagnosis of parasites in animals and humans. Nat. Protoc., v.5, p.503-515, 2010.

DEHLAWI, MS. The Occurrence of Nematodes In The Intestine of Local (baladi) Chicken (Gallus gallus domesticus) in Jeddah Province Saudi Arabia. Sci. J. King Faisal Univer. V.2, p.61-71, 2007
DOVC, A.; ZORMAN ROJS, O.; VERGLES

RATAJ, A. et al. Health status of free-living pigeons (Columba livia domestica) in the city of Ljubljana. Acta Vet. Hung., v.52, p.219-226, 2004.

DRANZOA, C., OCAIDO, M.; KATETE, P. (1999). The ecto, gastro-intestinal parasites in captive birds of Gnjarat zoos. Zoos Print J., v.15, p.295-296, 1999.

GHAZI, R. R.; KHATOON, N.; MANSOOR, S.; BILQEES, F. M. Pulluterina karachiensis sp.n. (Cestoda: Anaplocephalidae) from the wild pigeon Columba livia Gmelin. Turk. J. Zool., 26: 27-30, 2002

GICIK, Y.; BURGU, A. The helminth fauna in wild pigeons of Ankara and itsvicinity (in Turkish). Kafkas Üniv. Vet. Fak. Dergisi, v.6, p.1-7, 2000.

GREINER E.E. Parasite diagnosis by faecal examination. J. Assoc. Avian Vet., v.3, p. 69-72, 1989.

HARLIN, R.W. Pigeons. Vet. Clin. N. Am. Small Anim. Pract., v.24, p.157-173, 1994.

HAWKINS, P.A. Cited by Rajkhowa and Hazarika (2001). Indian Vet. J., v.78: p. 449-451, 1945.

IBRAHIM, A.I.; HASSANIN, H.H.; ALY, S.E.M.; ABDELAAL, A.A. A study on some parasitic infections in domestic pigeons in Ismailia province. Assiut Veterinary Medicine Journal, v.37, p.84-88, 1995.

IEPEMA, G.; WAGENAAR, JP.; BESTMAN, M. Parasitic worms in organic laying hens. Paper presented at Joint Organic Congress, Odense, Denmark, May 30-31, 2006.

JAVID, A.D.; TANVEER, S.; DAR, S.A. First report of Capillaria anatis (nematode: capillaridae) from corvus species of Kashmir India. Global Vet., v.10, p.467-471, 2013.

JORDAN, F.T.W.; PATTISON, M. Poultry diseases. London: W.B Saunders Company, 1996.p. 188-199.

JOSHI, P.K.; BOSE, M.; HARIS, D. Changes in certain haematological parameters in a siluroid catfish Clarias batrachus (Linn) exposed to a cadmium chloride. Pollut. Resour., v.21, p.129131, 2002. 
KAMINJO, J. S.; TIKASINGH, E.S.; FERDINAND, G.A. Parasites of the common pigeon (Columba livia) from the environs of Port of Spain, Trinidad. Bull. Anim. Health Prof, v.36, p.194-195, 1988.

KARAMON, J.; ZIOMKO, I.; CENCEK, T.; SROKA, J. Modified flotation method with the use of Percoll for the detection of Isospora suis oocysts in suckling piglet faeces. Vet. Parasitol., v.156, p.324-328, 2008.

KUMAR, R. A. survey of parasitic fauna of local pigeons and assessment of efficacy of certain drugs in poultry nematodiasis. 1998. M.V.Sc. thesis submitted to C.S Azad University of Agriculture and Technology, Kanpur.

LENINGRAD, E.,. Parasites of freshwater fish and the biological control. In: Israel Program for Scientific Translations. Jerusalem, p. 137-177, 1999.

LEVI, V.M. The pigeon. Levi Publication Co Inc., Sumter, SC. hirudinaceus and Ascaris suum. Vet. Parasitol., 61(1-2): 113-117, 1974.

MANUAL of veterinary parasitological laboratory techniques. London: Ministry of Agriculture, Fisheries and Food, 1986. 24p.

MARQUES, S.M.T.; QUADROS, R.M.; DASALIVA, R.M. et al. Parasites of pigeons (Columbalivia) in urban areas of lages, Southern Brazil. Parasitol. Latinoam., v.62, p.183-187, 2007.

NAEM A. 2013. Investigation on parasitic helminthes of gastrointestinal, liver and lung of domestic pigeons (Columba livia) in Urmia, Iran. Int. J. Livest. Res., v.3, p.35-41, 2013.

PATEL, P.V.; PATEL, A.I.; SAHU, R.K. ; VYAS, R.. Prevalence of gastrointestinal parasites in captive birds Gujrat Zoos. Zoo's Print J., v.15, p.295-296, 2000.

PERMIN, A.; BISGAARD, M.; FRANDSEN, F.; et al. Prevalence of gastrointestinal helminthes in different poultry production systems. British Poultry Science, v.40, p.439443, 1999.
PIASECKI, T. Evaluation of urban pigeon (Columbia livia f. urbana) health status in relation to their threat to human's health. Med. Wet., v.62, p.531-535, 2006.

REHMAN R. A study on the prevalence of Ascaridia galli and the effects of experimental infection on various blood parameters and body weight in the chicken. 1993. Thesis (M.Sc.) University. of Agriculture (CVS), FaisalabadPakistan.

RAZMI, G. R.; KALIDARI, G.A.; MALEKI, M. First report of the Hadjelia truncata infestation in pigeons of Iran. Iran. J. Vet. Res., v.8, p.175177, 2007.

SARI, B.; KARATEPE, B.; KARATEPE, M.; M. Parasites of domestic (Columba livia domestica) and wild (Columba livia livia) pigeons in Niğde, Turkey. Bul. Vet. Inst. Pulawy, v.52, p.551-554, 2008.

SENLIK, B.; GULEGEN, E.; AKYOL, V. Effect of age, sex and season the prevalence and intensity of helminthes infections in domest ic pigeons (Columba livia) from Bursa Province, Turkey. Acta Vet. Hung., v.53, p.449-456, 2005.

SOULSBY, E. J. L. Helminthes, arthropods and protozoa of domesticated animals. 7.ed. London: Bailliere Tindall, 1982. p.630- 637, 654.

TANVEER, M.K.; KAMRAN, A.; ABBAS, M. et al. Prevalence and chemo-therapeutical investigations of gastrointestinal nematodes in domestic pigeons in Lahore, Pakistan. Trop. Biomed., v.28, p.102-110, 2011.

URQUHART, G. M.; ARMOUR, J.; DUNCAN, J.L. et al. Veterinary parasitology. 2.ed. Harlow: Burnt Mill, 1996. p 256-257.

WEHR, E.E. Studies on the development of the pigeon capillarid, Capillaria columbae. [s.1.]: United States Department of Agriculture, 1930. 11p. (Technical Bulletin, 679).

WILLIAM, R.B. Avian malaria: clinical and chemical pathology of Plasmodium gallinaceum in the domestic fowl, Gallus gallus. Avian Pathol., v.34, p.29-47, 2005. 